Article

\title{
Potential of the Probiotic Lactobacillus Plantarum ATCC 14917 Strain to Produce Functional Fermented Pomegranate Juice
}

\author{
Ioanna Mantzourani ${ }^{1, *}$, Stavros Kazakos ${ }^{1}$, Antonia Terpou ${ }^{2}{ }^{\mathbb{D}}$, Athanasios Alexopoulos ${ }^{1}$, \\ Eugenia Bezirtzoglou ${ }^{1}$, Argyro Bekatorou ${ }^{2}$ and Stavros Plessas ${ }^{1, *}$ \\ 1 Laboratory of Microbiology, Biotechnology and Hygiene, Faculty of Agriculture Development, Democritus \\ University of Thrace, 68200 Orestiada, Greece; stkazak@yahoo.gr (S.K.); alexopo@agro.duth.gr (A.A.); \\ empezirt@agro.duth.gr (E.B.) \\ 2 Food Biotechnology Group, Department of Chemistry, University of Patras, GR-26504 Patras, Greece; \\ aterpou@upatras.gr (A.T.); abekatorou@upatras.gr (A.B.) \\ * Correspondence: imantzou@agro.duth.gr (I.M.); splessas@agro.duth.gr (S.P.); Tel.: +30-2552041137 (I.M.); \\ +30-2552041141 (A.B.); Fax: +30-2552041137 (I.M.); +30-2552041141 (A.B.)
}

Received: 4 December 2018; Accepted: 19 December 2018; Published: 22 December 2018

\begin{abstract}
In this research survey the application of probiotic strain Lactobacillus plantarum ATCC 14917 in pomegranate juice fermentation is sought. Pomegranate juice was fermented for $24 \mathrm{~h}$ and then it was stored 4 for 4 weeks. Cell viability retained in high levels after the $24 \mathrm{~h}$ of fermentation and storage for 4 weeks (above $8.8 \log \mathrm{cfu} / \mathrm{mL}$ ), while fermented pomegranate juice was scored better at the 4 th week of storage compared to non-fermented pomegranate juice. The probiotic strain was effective regarding lactic acid fermentation as was proved through sugar and organic acids analysis. Concentration of ethanol was maintained at low levels $(0.3-1 \% v / v)$. Fermented pomegranate juice contained more and in higher percentages desirable volatile compounds (alcohols, ketones and esters) even at the 4 th week of cold storage compared to non-fermented juice. Antioxidant activity (150.63 mg Trolox equivalent (TE)/100 mL at the 2nd week) and total phenolic content (206.46 mg gallic acid equivalents (GAE)/100 $\mathrm{mL}$ at the 2 nd week) were recorded in higher levels for all the storage time compared to non-fermented juice.
\end{abstract}

Keywords: Lactobacillus plantarum ATCC 14917; pomegranate juice; fruit; probiotic; antioxidant activity; phenolics; functional beverage

\section{Introduction}

Functional foods are being used worldwide as agents targeting to prevent disease [1]. As a result, functional foods have been gaining significant attention from the food industry during the past few years [2,3]. The international market of functional foods is rising and represents one of the most attractive areas of innovation regarding the food sector [4,5]. In general, functional foods exert beneficial health effects and include foods that contain bioactive compounds and probiotic [1]. Probiotics are live microorganisms (mainly bacteria but also yeasts) often called "good" or "helpful" because they promote the equilibrium of intestinal microflora [6,7]. Additionally, the consumption of probiotic food is indicated by many studies to reduce the level of serum cholesterol, to enhance the immune system and to prevent colon cancer [8]. However, probiotics should be present in adequate amounts in the food matrix in order to deliver their beneficial effects to the host [7]. Likewise, the minimum concentration of viable cells for a probiotic food product has been estimated to be approximately $10^{6}-10^{7} \mathrm{cfu} / \mathrm{mL}$ during the time of consumption [9]. In many studies, as well as industrial applications, the main vehicles for delivering probiotic bacteria have been demonstrated to 
be dairy products [10-12]. However, probiotic dairy products are often not suitable for consumption by certain groups of consumers due to increased incidence of lactose-intolerance, allergies, dyslipidemia and vegetarianism $[13,14]$. As a result of increasing consumers' demand for alternative non-dairy substrates for the delivery of probiotic bacteria, academic and industrial research was triggered toward the development of innovative juice and vegetable probiotic beverages [15-19].

Fruit juices and beverages market is currently demonstrating a dynamic growth worldwide [20,21]. Functional beverages manufactured with fruit or vegetable juices with incorporated probiotic bacteria are considered as an attractive option for those who do not consume dairy products [19]. In addition, fruit juices have been reported as novel suitable carrier for the delivery of probiotic bacteria as they are rich in vitamins, minerals and antioxidant compounds providing a suitable growth substrate in parallel with a strong health appeal $[15,16]$. Fermentation of fruit juice by probiotic bacteria can increase viability of the cells and in addition improve functional aspects of the produced beverage [16,22]. As a result, a wide variety of ongoing research has recently focused on fermented juice production by the use of various probiotic strains providing outstanding results [15,22-24]. Among many fruits, pomegranate juice is quite appreciated for its functional properties as it has potent anti-oxidative characteristics, anti-inflammatory and antimicrobial properties and has been previously employed for fermentation by probiotic lactic acid bacteria ameliorating the health benefits of the juice [25-28].

The main aim of this study was the development of a novel fermented pomegranate beverage by the application of Lactobacillus plantarum ATCC 14917 [29]; a probiotic strain with good technological characteristics which was evaluated in the frame of this research. The parameters that were analyzed mainly focused on (i) concentration of residual sugars, organic acids and ethanol, (ii) volatile compounds, (iii) total phenolics content, (iv) antioxidant activity and (v) viability of the strain. To the best of our knowledge, no previous studies demonstrated the effect of pomegranate probiotic juice fermentation during cold storage $\left(4^{\circ} \mathrm{C}\right)$ for four weeks besides the $24 \mathrm{~h}$ of fermentation.

\section{Materials and Methods}

\subsection{Microorganism}

The probiotic strain Lactobacillus plantarum ATCC 14917 was selected and applied in the fermentations [29]. It was grown under anaerobic conditions at $37{ }^{\circ} \mathrm{C}$ for $48 \mathrm{~h}$ in MRS broth. Wet biomass was harvested by centrifugation (Sigma 3K12, Bioblock Scientific, Lezennes, France) at $5000 \mathrm{rpm}$ for $10 \mathrm{~min}$ at $25^{\circ} \mathrm{C}$. All media were autoclaved at $120^{\circ} \mathrm{C}$ and at $1-1.5 \mathrm{~atm}$ for $15 \mathrm{~min}$ prior to use.

\subsection{Pomegranate Juice Fermentation}

Pomegranates (Punica granatum L.) were obtained by a local market (Orestiada, Greece). They were washed and processed into juice by blending the seeds for $10 \mathrm{~min}$. Sterilized water was added to adjust the initial sugar concentration to approximately $90 \mathrm{~g} / \mathrm{L}$, and the initial $\mathrm{pH}$ was adjusted to 3.5 with $\mathrm{NaOH} 4 \mathrm{~N}$. The prepared juice solutions $(100 \mathrm{~mL})$ were transferred into $250 \mathrm{~mL}$ flasks and pasteurized for $5 \mathrm{~min}$ at $80^{\circ} \mathrm{C}$, cooled at room temperature and finally used for the fermentations [26]. $1 \mathrm{~g}$ of harvested (wet weight) Lactobacillus plantarum ATCC 14917 was added to $100 \mathrm{~mL}$ of pomegranate juice that was fermented at $30{ }^{\circ} \mathrm{C}$ for $24 \mathrm{~h}$. The initial cell viability was determined at $11.42 \log \mathrm{cfu} / \mathrm{mL}$ of juice. Then, the flaks were kept at $4{ }^{\circ} \mathrm{C}$ for 28 days ( 4 weeks). The fermentations were carried out in triplicate.

\subsection{Ethanol and Residual Sugar Analysis}

Samples were collected at various time intervals (days $0,1,7,14,21$ and 28) and were analyzed for residual sugar (glucose, fructose and sucrose), and ethanol concentration, by high performance liquid chromatography on a Shimadzu HPLC system (Shimadzu, Kyoto, Japan) consisting of a SCR-101N stainless steel column, a LC-9A pump, a CTO-10A oven set at $60{ }^{\circ} \mathrm{C}$ and a RID-6A refractive index 
detector. Ultra-pure water obtained by a Milli-Q water purifying system (resistivity $18.2 \mathrm{M} \Omega \mathrm{cm}^{-1}$, Darmstadt, Germany).) was used as mobile phase with a flow rate of $0.8 \mathrm{~mL} / \mathrm{min}$, and 1-butanol $(0.1 \%$ $v / v)$ was used as internal standard. Samples were filtered through $0.2 \mu \mathrm{m}$ microfilters, before injection. Ethanol $(\% v / v)$ and residual sugar $(\mathrm{g} / \mathrm{L})$ concentrations were calculated using standard curves. All results are presented as means of at least three repetitions plus standard deviations.

\subsection{Organic Acid Analysis}

Organic acids (lactic and acetic) were determined by ion-exchange liquid chromatography as described before by Plessas, et al. [30]. The analysis was performed on an ion-exchange HPLC Shimadzu system consisting of a Shim-pack ICA1 column, an LC-10AD pump, a CTO-10A oven, and a CDD-6A conductivity detector. A solution of $2.5 \mathrm{mM}$ phthalic acid and $2.4 \mathrm{mM}$ tris (hydroxymethyl) aminomethane ( $\mathrm{pH} 4.0)$ was used as mobile phase $(1.2 \mathrm{~mL} / \mathrm{min})$. The column temperature was $40{ }^{\circ} \mathrm{C}$. The sample dilution was $5 \% v / v$, and the injection volume was $60 \mu \mathrm{L}$. Determinations were carried out using standard curves.

\subsection{Microbiological Analysis}

Aliquots of $10 \mathrm{~mL}$ were collected from each pomegranate juice (after homogenisation by shaking thoroughly) at various time intervals during fermentation and storage. The samples were blended with $90 \mathrm{~mL}$ of sterile 1/4 strength Ringer's solution (Sigma-Aldrich) and mixed in a stomacher blender and subjected to serial decimal dilutions in 1/4 strength Ringer's solution. Viable counts of lactobacilli, yeasts and fungi, and coliforms were determined in triplicate by plating appropriate dilutions on the selective media for each species [31]. Specifically, viable counts of Lactobacillus plantarum were enumerated on acidified MRS agar (Merck, Darmstadt, Germany) at $37^{\circ} \mathrm{C}$ for $72 \mathrm{~h}$, anaerobically (Anaerobic jar, Anerocult C, Merck, Darmstadt, Germany). Coliforms were enumerated on Violet Red Bile agar (Lab M, Lancashire, UK) after incubation at $30^{\circ} \mathrm{C}$ for $24 \mathrm{~h}$. Yeasts and fungi were determined by plating on Sabouraud Chloramphenicol Agar (Merck, Germany) after incubation at $30^{\circ} \mathrm{C}$ for $72 \mathrm{~h}$. All cell counts were expressed as log of mean colony forming units (cfu) per $\mathrm{mL}$ of pomegranate juice. All results are presented as means of three repetitions plus standard deviations.

\subsection{Total Phenolics and Antioxidant Activity}

Total phenolic content was determined by using the Folin-Ciocalteu reagent (Sigma, St. Louis, MO, USA) based on colorimetric reduction [32]. The phenolic compounds are oxidized to phenolates by the reagent at alkaline $\mathrm{pH}$ in a saturated solution of sodium carbonate resulting in a blue complex. About $1 \mathrm{~mL}$ of Folin-Ciocalteau $(10 \%, w / v$,$) is added to 0.2 \mathrm{~mL}$ of prepared pomegranate juice, followed by the addition of $1.2 \mathrm{~mL}$ of aqueous $\mathrm{Na}_{2} \mathrm{CO}_{3}(7.5 \%, w / v)$. The mixture was left in the dark for $90 \mathrm{~min}$. The absorbance of the blue color solution was monitored at $760 \mathrm{~nm}$ on a UV visible spectrophotometer (Shimadzu, Kyoto, Japan), against blank (distilled water). The total phenolics content (TPC) was assessed by plotting the gallic acid calibration curve and expressed as $\mathrm{mg}$ of gallic acid equivalents (GAE)/100 ml juice. The antioxidant activity (AA) of pomegranate juices was evaluated applying the ABTS radical cation decolorization assay [33]. $\mathrm{ABTS}^{+}$was prepared by reacting of ABTS with potassium persulfate. Samples were analyzed at five different dilutions, within the linearity range of the assay, as previously described by Gentile, et al. [34]. TAA was expressed as mg of Trolox equivalent (TE) $/ 100 \mathrm{~mL}$ juice. All measurements were repeated three times. All measurements were repeated three times.

\subsection{Volatiles Analysis by HS-SPME/GC-MS}

The volatiles of the fermented pomegranate juices were determined using Gas Chromatography/ Mass Spectrometry with Headspace Solid-Phase Micro-Extraction sampling (HS-SPME/GC-MS), as described by Vázquez-Araújo, et al. [35] with small modifications. Each sample (2 mL) was pipetted into $4 \mathrm{~mL}$ glass vial and sealed with a screw-cap with PTFE-lined silicone septum. The vials were 
placed in a water-bath at $40^{\circ} \mathrm{C}$ and magnetically stirred at $250 \mathrm{rpm}$ for $5 \mathrm{~min}$ before exposing the fibre (DVB/CAR/PDMS, needle size 24 ga, length $1 \mathrm{~cm}$, Sigma Aldrich) for $30 \mathrm{~min}$ at the same conditions. Desorption of volatiles was affected at $250{ }^{\circ} \mathrm{C}$ for $2 \mathrm{~min}$ (splitless) in the inlet of GC-MS system (Shimadzu QP-2010 Ultra). The fibre was then held in the inlet (split ratio 1/50) for another $8 \mathrm{~min}$ to prevent carryover effects. Compounds were separated on a MEGA- 5 HT column $(30 \mathrm{~m} \times 0.25 \mathrm{~mm}$ i.d., film thickness $0.25 \mu \mathrm{m}$, Mega s.n.c., Legnano, Italy) using helium as a carrier gas at a constant linear velocity $(35 \mathrm{~cm} / \mathrm{s})$. During analysis, the oven was kept at $40{ }^{\circ} \mathrm{C}$ for $5 \mathrm{~min}$, then increased with $4{ }^{\circ} \mathrm{C} / \mathrm{min}$ up to $150{ }^{\circ} \mathrm{C}$ followed by $30^{\circ} \mathrm{C} / \mathrm{min}$ up to $260^{\circ} \mathrm{C}$, and held for $5 \mathrm{~min}$. The mass spectrometer was operated in the electron ionization mode with the electron energy set at $70 \mathrm{eV}$ and scan mass range of $40-400 \mathrm{~m} / \mathrm{z}$. Source and interface temperatures were set at 200 and $270{ }^{\circ} \mathrm{C}$ respectively. Identification of the compounds was affected by comparing: (i) the linear retention indices based on the homologous series of n-alkanes (C7-C24) with those of reference compounds and those of NIST14 and FFNSC MS library (Chromaleont S.r.l., Messina, Italy), (ii) MS data with those of reference compounds and by MS data obtained from NIST14 and FFNSC libraries. GC-MS solution (Shimadzu) and Amdis (National Institute of Standards and Technology-NIST) software were used in the identification process. The relative amounts of individual components were calculated on the basis of peak area (from Amdis) without using any correction factor.

\subsection{Sensory Evaluation}

Sensory evaluation of the fermented pomegranate beverages was performed by a panel of 30 non-trained laboratory members who scored the aroma, taste and overall acceptability in comparison with commercial pomegranate juice, after the end of juice fermentation and during storage at $4{ }^{\circ} \mathrm{C}$ [36]. The samples were coded by a different 3-digital number and were served in a randomized order, while the panel was asked to evaluate them based on 0-10 preference scale. The results are presented as average scores plus standard deviations

\subsection{Statistical Analysis}

The data obtained from physicochemical characteristics, antioxidant activity, total phenolics content and cell viability of the non-fermented and fermented pomegranate juice were analyzed for their mean differences with the Analysis of Variance (ANOVA) procedure followed by Duncan's post hoc multiple range test to extract the specific differences between the various treatments. Analysis was performed by using IMB SPSS v20 (IBM Corp., Armonk, NY, USA) at an alpha level of 5\%.

\section{Results and Discussion}

\subsection{Cell Viability}

The viability of Lactobacillus plantarum ATCC 14917 as well as possible spoilage by yeasts and fungi or coliforms were recorded after juice fermentation and during the four weeks of storage at $4{ }^{\circ} \mathrm{C}$ (Table 1). According to the results, cell viability of the probiotic Lactobacillus plantarum strain was maintained at high levels throughout three weeks of cold storage (above $10 \log \mathrm{cfu} / \mathrm{mL}$ ), while decreased during the last week of storage (statistically significant). Specifically, viable probiotic cell counts were decreased to $8.83 \log \mathrm{cfu} / \mathrm{mL}$ at the last week of storage (4th). However, even in this case, the recorded viability value was above the limit of 6-7 $\log \mathrm{cfu} / \mathrm{mL}$, which is required for probiotic products [9]. At this point, it should be underlined that, the initial $\mathrm{pH}$ value of the freshly prepared pomegranate juice used in this study was approximately 3.0. Likewise, before fermentation, a slight increase of the substrate $\mathrm{pH}$ (with $\mathrm{NaOH} 4 \mathrm{~N}$ ) was made to a value of 3.5, so as to make the pomegranate juice more fermentable by Lactobacillus plantarum ATCC 14917 (Table 1). 
Table 1. Viability of the Lactobacillus plantarum ATCC 14917 cells in the fermented pomegranate juices after fermentation $\left(24 \mathrm{~h}\right.$ in $\left.30^{\circ} \mathrm{C}\right)$ and over 4 weeks of storage at $4{ }^{\circ} \mathrm{C}$.

\begin{tabular}{ccccc}
\hline \multirow{2}{*}{ Temperature $\left({ }^{\circ} \mathrm{C}\right)$} & Time & \multicolumn{3}{c}{ Viability $(\log \mathbf{c f u} / \mathbf{m L})$} \\
\cline { 3 - 5 } & & Lactobacillus Plantarum ATCC 14917 & Yeasts \& Fungi & Coliforms \\
\hline 30 & 0 & $11.42 \pm 0.16^{\mathrm{a}}$ & 0 & 0 \\
30 & $24 \mathrm{~h}$ & $10.51 \pm 0.15^{\mathrm{a}}$ & 0 & 0 \\
4 & Week 1 & $10.23 \pm 0.94^{\mathrm{a}}$ & 0 & 0 \\
4 & Week 2 & $10.54 \pm 0.26^{\mathrm{a}}$ & 0 & 0 \\
4 & Week 3 & $10.28 \pm 0.27^{\mathrm{a}}$ & 0 & 0 \\
4 & Week 4 & $8.83 \pm 0.58^{\mathrm{b}}$ & 0 & 0 \\
\hline
\end{tabular}

Similar superscript letters in columns denote no significant differences at an alpha $=0.05$ (ANOVA, Duncan Post Hoc Multiple Comparisons).

A possible explanation of the high levels of Lactobacillus plantarum ATCC 14917 viability during storage is that lactic acid fermentation might have increased the bio accessibility of phenolic compounds. There are reports from the literature claiming that phenolic compounds may act as prebiotics [37]. Likewise, possible prebiotic activity led to the amelioration of the growth of Lactobacillus plantarum ATCC 14917. In addition, it has been noted that some strains of Lactobacillus plantarum can grow in fruit matrices due to their tolerance to acidic environments [38]. Indeed, Lactobacillus plantarum ATCC 14917 has been reported to exhibit high acid resistance ability [29]. Furthermore, no spoilage of the fermented pomegranate juice, by yeasts, fungi and coliforms was observed even after the 4th week of storage at $4{ }^{\circ} \mathrm{C}$ (Table 1). It seems that lactic acid fermentation of pomegranate juice could provide a protective effect from microbiological spoilage as also reported by previous studies $[39,40]$.

\subsection{Ethanol, Organic Acids and Residual Sugar Concentrations}

The results obtained for residual sugar, lactic and acetic acid and ethanol are presented in Table 2.

Table 2. Analysis of sugars, organic acids and ethanol in the pomegranate juices fermented by $L$. plantarum ATCC 14917 at first $24 \mathrm{~h}$ at $30^{\circ} \mathrm{C}$ and during storage at $4{ }^{\circ} \mathrm{C}$ for 4 weeks.

\begin{tabular}{ccccc}
\hline Time & Sugars (g/L) & Lactic Acid (g/L) & Acetic Acid (g/L) & Ethanol (\% v/v) \\
\hline 24 h & $82.6 \pm 0.5^{\mathrm{a}}$ & $1.26 \pm 0.07^{\mathrm{a}}$ & $<0.1$ & $0.3 \pm 0.1^{\mathrm{a}}$ \\
Week 1 & $75.3 \pm 0.9^{\mathrm{b}}$ & $2.86 \pm 0.08^{\mathrm{b}}$ & $<0.1$ & $0.43 \pm 0.06^{\mathrm{a}}$ \\
Week 2 & $75.2 \pm 2.1^{\mathrm{b}}$ & $2.87 \pm 0.06^{\mathrm{b}}$ & $0.30 \pm 0.10^{\mathrm{a}}$ & $0.73 \pm 0.06^{\mathrm{b}}$ \\
Week 3 & $65.0 \pm 0.8^{\mathrm{c}}$ & $3.12 \pm 0.07^{\mathrm{c}}$ & $0.43 \pm 0.05^{\mathrm{b}}$ & $1.0 \pm 0.1^{\mathrm{c}}$ \\
Week 4 & $62.9 \pm 0.8^{\mathrm{c}}$ & $3.75 \pm 0.09^{\mathrm{d}}$ & $0.86 \pm 0.05^{\mathrm{c}}$ & $1.0 \pm 0.1^{\mathrm{c}}$ \\
\hline
\end{tabular}

Similar superscript letters in columns denote no significant differences at an alpha $=0.05$ (ANOVA, Duncan Post Hoc Multiple Comparisons).

According to the results, residual sugar levels were decreased while the levels of organic acids were increased, demonstrating the efficiency of the strain Lactobacillus plantarum ATCC 14917 for lactic acid fermentation of pomegranate juice. In particular, the residual sugars concentration was reduced (statistically significant) by approximately $20 \%(65.0 \mathrm{~g} / \mathrm{L})$ and $23 \%(62.9 \mathrm{~g} / \mathrm{L})$ after the $3 \mathrm{rd}$ and the 4 th weeks of storage respectively. On the other hand, the level of lactic acid increased (statistically significant) every week reaching its maximum value at the 4 th week of storage $(3.75 \mathrm{~g} / \mathrm{L})$, while acetic acid concentration was determined after the 2 nd week reaching its maximum value at the last week $(0.86 \mathrm{~g} / \mathrm{L})$. Ethanol concentration significantly increased from $0.3 \%$ after $24 \mathrm{~h}$ of fermentation to $1.0 \%$ $(v / v)$ at the end of the 3th and 4th week of storage. 


\subsection{Total Phenolics and Antioxidant Activity}

The results concerning the total phenolics content (TPC) and antioxidant activity (AA) of non-fermented and fermented pomegranate juice by Lactobacillus plantarum ATCC 14917 are presented in Figure 1.

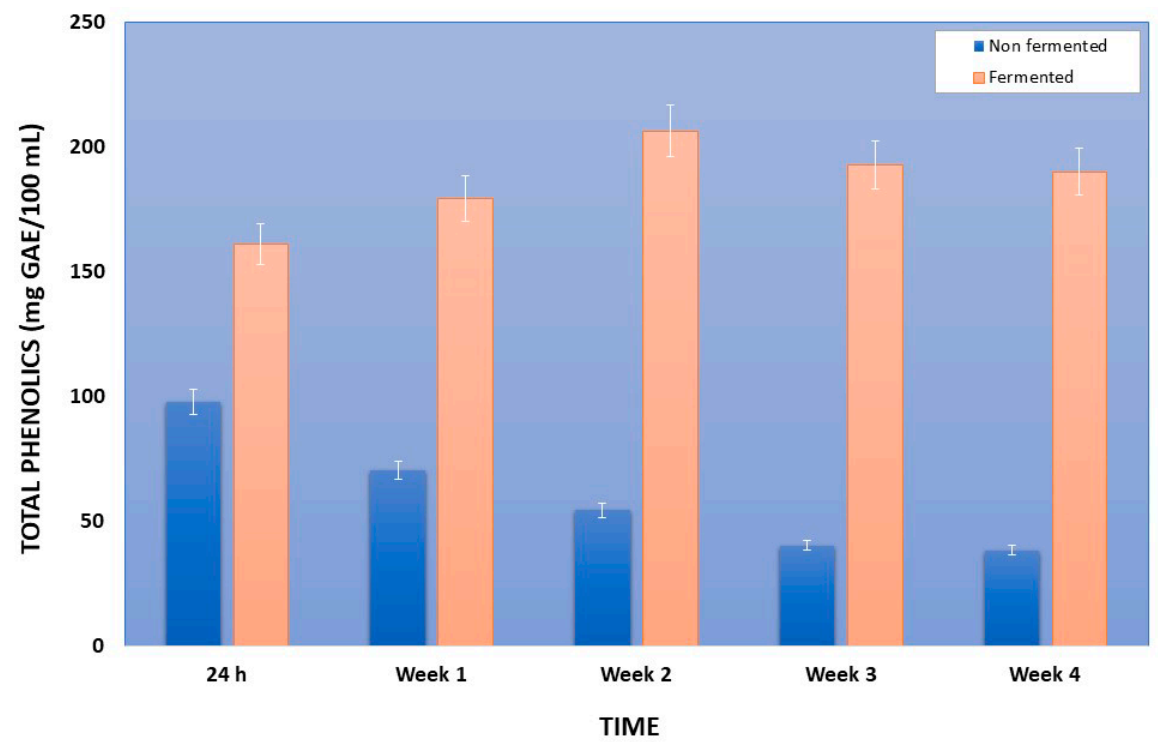

Figure 1. Total phenolics of fermented with Lactobacillus plantarum ATCC 14917 and non-fermented pomegranate juice and at first $24 \mathrm{~h}$ at $30{ }^{\circ} \mathrm{C}$ and during storage at $4{ }^{\circ} \mathrm{C}$ for 4 weeks. GAE, gallic acid equivalents.

Initial total phenolics content of freshly prepared pomegranate juice was about $111 \pm 10 \mathrm{mg}$ GAE/100 mL. The total phenolics content (TPC) of the fermented pomegranate juice significantly increased during the $24 \mathrm{~h}$ fermentation and was higher in all 4 weeks of storage compared to the respective values of non-fermented pomegranate juice. Specifically, after the first 24 -h fermentation, total phenolics content of the fermented pomegranate juice significantly increased to an average of $161.04 \mathrm{mg}$ GAE $/ 100 \mathrm{~mL}$, compared to the respective value of the non-fermented juice (control) that was decreased to $97.94 \mathrm{mg}$ GAE/100 mL, (Figure 1). This statistically significant increase of TPC of fermented pomegranate juice was observed also in all the weeks of storage time (4 weeks), reaching its maximum value at the 2 nd week $(206.46 \mathrm{mg} \mathrm{GAE} / 100 \mathrm{~mL}$ ), while TPC of non-fermented pomegranate juice decreased to $38.43 \mathrm{mg} \mathrm{GAE} / 100 \mathrm{~mL}$ at the 4 th week of storage. It has been reported in the literature that lactic acid fermentation enhances the total phenolics content of fruit juices including pomegranate [41-43]. Other researchers who have demonstrated the same outcome reported that improvements in TPC of pomegranate juice can be related to the increase in the free form of phenolic compounds through the fermentation and the production of new phenolic derivatives such as catechin and $\alpha$-punicalagin [37,44,45].

Regarding the antioxidant activity (AA) of fermented pomegranate juice similar outcome was observed as in the case of TPC (Figure 2). Particularly, initial AA of freshly prepared pomegranate juice was about $90 \pm 15 \mathrm{mg}$ TE/100 mL. During the first 24-h fermentation AA of the fermented pomegranate juice significantly increased to an average of $119.05 \mathrm{mg} \mathrm{TE} / 100 \mathrm{~mL}$, compared to the respective value of the non-fermented juice (control) that was decreased to $85.33 \mathrm{mg} \mathrm{TE} / 100 \mathrm{~mL}$ (Figure 2). This statistically significant increase of AA of fermented pomegranate juice was observed also in all the weeks of storage time (4 weeks), showing an increase of approximately $32 \%$ the $3 \mathrm{rd}$ week of storage (132.79 mg TE/100 mL), while AA of non-fermented pomegranate juice decreased constantly (approximately 60\%) to $33.98 \mathrm{mg}$ TE/100 mL the last week of storage. A possible explanation of this finding is that lactic acid fermentation ameliorated the AA of pomegranate juice which is in 
accordance with other reports in literature [46]. Specifically, other researchers have demonstrated that some bacteria are capable of producing $\beta$-galactosidase catalyzing the release of phenolic compounds from the bonded sugar [47]. This process may lead to an increase in the antioxidant activity after fermentation [48-50].

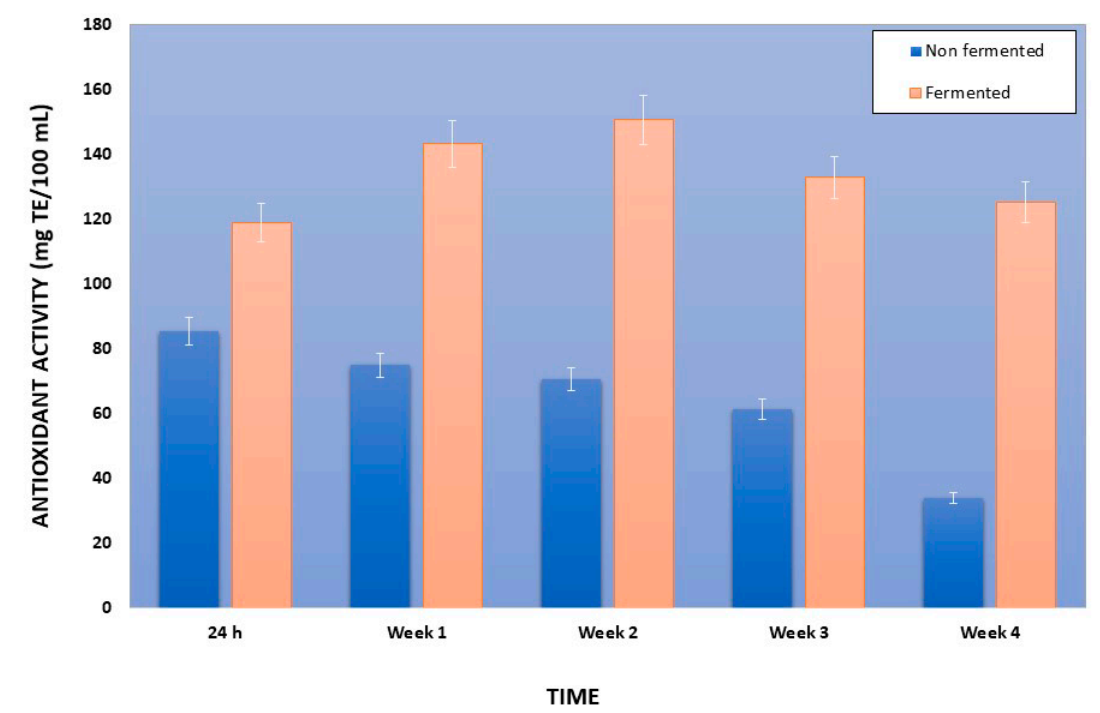

Figure 2. Antioxidant activity of fermented with Lactobacillus plantarum ATCC 14917 and non-fermented pomegranate juice and at first $24 \mathrm{~h}$ at $30^{\circ} \mathrm{C}$ and during storage at $4{ }^{\circ} \mathrm{C}$ for 4 weeks. TE, Trolox equivalent.

\subsection{Volatiles Composition and Sensory Evaluation}

The composition of headspace volatile compounds that were identified by SPME GC/MS in the non-fermented (NF) and fermented pomegranate (F) juice at 0 and $24 \mathrm{~h}$ of fermentation as well as at the 4th week of storage is presented in Table 3. Statistical analysis was conducted between normalized peak area \% of each volatile of NF and F pomegranate juice. Alcohols, aldehydes, ketones and esters were the predominant compounds identified. In particular, 13 alcohols, 11 aldehydes, 11 ketones, 10 esters, 7 terpenoids and furfural were identified in the fermented pomegranate juice. All these compounds have been previously identified in pomegranate juices/fruit/seeds, fermented pomegranate juice by lactic acid bacteria and other fruits (apples, berries, plums, citrus, exotic fruit, etc.) or fruit beverages $[35,51-57]$.

Fermented pomegranate juice $(\mathrm{F})$ seems to contain more desirable compounds compared to non-fermented pomegranate juice (NF). Specifically, F contained more and higher amounts of alcohols, ketones and esters and less amounts of aldehydes after $24 \mathrm{~h}$ of fermentation and at the 4 th week of storage. This outcome is very significant since it is well established in the literature that: (i) alcohols contribute positively in the flavor profile due to floral attributes such as 2-ethyl-1-hexanol [51], (ii) aldehydes are non-desirable compounds in pomegranate juices [51,58], (iii) ketones can deliver several positive sensory/aroma attributes [59] and (iv) esters play an important role in contributing to fruity notes of fruit juices [60]. Likewise, it is obvious that lactic acid fermentation affected positively the flavor of pomegranate juice. Finally, various common terpenes originating from pomegranate juice $[35,56]$ were found in both non-fermented and fermented pomegranate juice. In particular, p-cymene, D-limonene, eucalyptol, linalool, camphor, terinen-4-ol and $\alpha$-terpineol were identified. 
Table 3. Volatile compounds identified in the non-fermented (NF) and fermented pomegranate juice (F) by Lactobacillus plantarum ATCC 14917 at $0 \mathrm{~h}$ and $24 \mathrm{~h}$ of fermentation as well at the 4 th week of storage.

\begin{tabular}{|c|c|c|c|c|c|c|c|}
\hline \multirow{3}{*}{ Compound } & \multirow{3}{*}{$\mathrm{RI}^{1}$} & \multirow{3}{*}{$0 \mathrm{~h}$} & \multicolumn{4}{|c|}{ Normalized Peak Area \% } & \multirow{3}{*}{ Identification } \\
\hline & & & & & & & \\
\hline & & & $\mathbf{F}$ & NF & $\mathbf{F}$ & $\mathrm{NF}$ & \\
\hline \multicolumn{8}{|l|}{ Alcohols } \\
\hline Ethyl alcohol & 467 & $0.4 \pm 0.1$ & $10.0 \pm 0.8^{\mathrm{a}}$ & $6.0 \pm 0.1^{b}$ & $44.6 \pm 1.2^{\mathrm{a}}$ & $19.8 \pm 0.8^{\mathrm{b}}$ & MS, RI, ref \\
\hline 1-Butanol & 633 & $3.4 \pm 0.1$ & $6.1 \pm 0.2^{\mathrm{a}}$ & $2.0 \pm 0.3^{\mathrm{b}}$ & $2.5 \pm 0.7^{b}$ & $10.8 \pm 0.1^{\mathrm{a}}$ & MS, RI, ref \\
\hline 3-Methyl-1-butanol & 726 & $2.2 \pm 0.4$ & $3.0 \pm 0.3^{\mathrm{a}}$ & $1.0 \pm 0.3^{\mathrm{b}}$ & $3.8 \pm 0.6$ & nd & MS, RI, ref \\
\hline 2-Methyl-1-butanol & 728 & $0.9 \pm 0.1$ & $<0.1$ & $0.6 \pm 0.1^{\mathrm{a}}$ & $1.0 \pm 0.1^{\mathrm{b}}$ & $1.7 \pm 0.1^{\mathrm{a}}$ & MS, RI, ref \\
\hline 3-Methyl-3-buten-1-ol & 724 & $1.2 \pm 0.1$ & $7.0 \pm 0.5^{\mathrm{a}}$ & $2.0 \pm 0.3^{\mathrm{b}}$ & $0.7 \pm 0.1$ & nd & MS, RI, ref \\
\hline (E)-3-Hexen-1-ol & 854 & $3.9 \pm 0.1$ & $3.4 \pm 0.3$ & nd & $5.4 \pm 0.2$ & nd & MS, RI, ref \\
\hline (Z)-3-Hexen-1-ol & 864 & $<0.1$ & $0.8 \pm 0.2^{b}$ & $6.5 \pm 0.3^{\mathrm{a}}$ & $1.6 \pm 0.2$ & nd & MS, RI, ref \\
\hline 1-Hexanol & 869 & $15 \pm 1.2$ & $4.8 \pm 0.2^{\mathrm{a}}$ & $1.5 \pm 0.2^{b}$ & $6.1 \pm 0.3$ & nd & MS, RI, ref \\
\hline 2-Heptanol & 903 & $0.4 \pm 0.1$ & $<0.1$ & $1.8 \pm 0.1^{\mathrm{a}}$ & nd & nd & MS, RI, ref \\
\hline 2-Ethyl-1-hexanol & 1032 & $0.9 \pm 0.2$ & $1.3 \pm 0.1$ & nd & $2.4 \pm 0.2$ & nd & MS, RI, ref \\
\hline 1-Nonanol & 1177 & $1.5 \pm 0.2$ & $1.0 \pm 0.1$ & nd & nd & nd & MS, RI, ref \\
\hline 1-Decanol & 1413 & $0.3 \pm 0.1$ & $0.5 \pm 0.1 \mathrm{ab}$ & $0.5 \pm 0.1 \mathrm{ab}$ & nd & nd & MS, RI, ref \\
\hline 1-Dodecanol & 1480 & $0.3 \pm 0.1$ & $0.5 \pm 0.1^{\mathrm{ab}}$ & $0.5 \pm 0.1^{\mathrm{ab}}$ & nd & nd & MS, RI, ref \\
\hline \multicolumn{8}{|l|}{ Aldehydes } \\
\hline Acetaldehyde & 459 & $0.4 \pm 0.1$ & $0.8 \pm 0.1$ & $<0.1$ & $<0.1$ & nd & MS, RI \\
\hline 3-Methyl-butanal & 615 & $1.0 \pm 0.1$ & $0.6 \pm 0.2^{b}$ & $2.8 \pm 0.2^{\mathrm{a}}$ & $<0.1$ & $6.1 \pm 0.3$ & MS, RI \\
\hline 2-Methyl-butanal & 630 & $0.7 \pm 0.1$ & $0.5 \pm 0.1^{b}$ & $3.9 \pm 0.1^{\mathrm{a}}$ & $<0.1$ & $5.1 \pm 0.2$ & MS, RI \\
\hline Hexanal & 795 & $1.1 \pm 0.3$ & $0.6 \pm 0.1^{\mathrm{a}}$ & $0.3 \pm 0.1^{b}$ & $<0.1$ & $2.9 \pm 0.1$ & MS, RI, ref \\
\hline Heptanal & 903 & $0.4 \pm 0.1$ & $<0.1$ & $6.5 \pm 0.8$ & $<0.1$ & $11.2 \pm 0.1$ & MS, RI \\
\hline Benzaldehyde & 957 & $<0.1$ & $<0.1$ & $13.2 \pm 1.1$ & $<0.1$ & $1.2 \pm 0.1$ & MS, RI, ref \\
\hline Octanal & 1004 & $<0.1$ & $<0.1$ & $2.7 \pm 0.4$ & $<0.1$ & $7.5 \pm 0.8$ & MS, RI, ref \\
\hline Benzeneacetaldehyde & 1042 & $<0.1$ & $1.3 \pm 0.1^{b}$ & $12.4 \pm 0.8^{\mathrm{a}}$ & $0.9 \pm 0.1^{b}$ & $11.5 \pm 0.9^{\mathrm{a}}$ & MS, RI \\
\hline Nonanal & 1105 & $0.5 \pm 0.2$ & $11.7 \pm 0.9^{\mathrm{a}}$ & $9.0 \pm 0.4^{b}$ & $2.0 \pm 0.1^{b}$ & $8.0 \pm 0.4^{\mathrm{a}}$ & MS, RI \\
\hline Undecanal & 1310 & $<0.1$ & $<0.1$ & $2.4 \pm 0.4^{\mathrm{a}}$ & nd & $4.5 \pm 0.5$ & MS, RI \\
\hline Dodecanal & 1412 & $<0.1$ & $<0.1$ & $5.0 \pm 0.3^{a}$ & nd & $2.1 \pm 0.2$ & MS, RI \\
\hline \multicolumn{8}{|l|}{ Ketones } \\
\hline 2,3-Butanedione & 533 & $0.7 \pm 0.1$ & $<0.1$ & $<0.1$ & $<0.1$ & nd & MS, RI, ref \\
\hline 2-Butanone & 542 & $1.9 \pm 0.3$ & $0.7 \pm 0.1^{b}$ & $1.5 \pm 0.2^{\mathrm{a}}$ & $1.1 \pm 0.1$ & nd & MS, RI \\
\hline 2-Pentanone & 678 & $2.9 \pm 0.3$ & $0.9 \pm 0.1^{\mathrm{a}}$ & $0.5 \pm 0.1^{\mathrm{b}}$ & $0.9 \pm 0.1$ & nd & MS, RI \\
\hline 3-Pentanone & 700 & $2.5 \pm 0.1$ & $1.9 \pm 0.1^{\mathrm{a}}$ & $<0.1$ & $8.1 \pm 0.1$ & nd & MS, RI \\
\hline 3-Hexanone & 777 & $1.1 \pm 0.2$ & $1.6 \pm 0.1^{\mathrm{a}}$ & $0.8 \pm 0.1^{\mathrm{b}}$ & $0.8 \pm 0.1$ & nd & MS, RI \\
\hline 2-Hexanone & 784 & $1.1 \pm 0.1$ & $2.8 \pm 0.3^{\mathrm{a}}$ & $1.6 \pm 0.1^{b}$ & $1.1 \pm 0.1$ & nd & MS, RI \\
\hline 2-Heptanone & 893 & $0.4 \pm 0.1$ & $1.6 \pm 0.1 \mathrm{ab}$ & $0.6 \pm 0.1 \mathrm{ab}$ & $2.5 \pm 0.1$ & $<0.1$ & MS, RI \\
\hline 3-Heptanone & 887 & $0.3 \pm 0.1$ & $2.3 \pm 0.1 \mathrm{ab}$ & $0.6 \pm 0.1^{\mathrm{a}}$ & $2.5 \pm 0.1$ & $<0.1$ & MS, RI \\
\hline 4-Methyl-2-heptanone & 939 & $14.5 \pm 1.4$ & $9.1 \pm 0.3^{\mathrm{a}}$ & $1.2 \pm 0.1^{\mathrm{a}}$ & $8.4 \pm 0.4$ & nd & MS, RI \\
\hline 6-Methyl-5-hepten-2-one & 990 & $0.4 \pm 0.1$ & $<0.1$ & $0.8 \pm 0.1^{\mathrm{a}}$ & nd & $0.6 \pm 0.1$ & MS, RI \\
\hline 2-Nonanone & 1094 & $<0.1$ & $1.1 \pm 0.1^{\mathrm{b}}$ & $0.5 \pm 0.1^{\mathrm{a}}$ & nd & $0.8 \pm 0.1$ & MS, RI \\
\hline
\end{tabular}


Table 3. Cont.

\begin{tabular}{|c|c|c|c|c|c|c|c|}
\hline \multirow{3}{*}{ Compound } & \multirow{3}{*}{$\mathrm{RI}^{1}$} & & \multicolumn{4}{|c|}{ Normalized Peak Area \% } & \multirow{3}{*}{ Identification $^{2}$} \\
\hline & & $0 \mathrm{~h}$ & \multicolumn{2}{|c|}{$24 \mathrm{~h}$} & \multicolumn{2}{|c|}{ 4th week } & \\
\hline & & & F & NF & $\mathbf{F}$ & $N F$ & \\
\hline \multicolumn{8}{|l|}{ Esters } \\
\hline Methyl acetate & 494 & $1.9 \pm 0.2$ & $1.5 \pm 0.1^{\mathrm{ab}}$ & $1.3 \pm 0.1^{\mathrm{ab}}$ & $0.8 \pm 0.1^{\mathrm{ab}}$ & $0.4 \pm 0.1^{\mathrm{ab}}$ & MS, RI, ref \\
\hline Ethyl acetate & 560 & $1.9 \pm 0.1$ & $1.4 \pm 0.2^{\mathrm{a}}$ & $1.8 \pm 0.1^{b}$ & $1.0 \pm 0.2^{\mathrm{a}}$ & $1.5 \pm 0.1^{b}$ & MS, RI, ref \\
\hline n-Propyl acetate & 711 & $0.6 \pm 0.1$ & $0.9 \pm 0.1$ & nd & $0.9 \pm 0.1$ & nd & MS, RI, ref \\
\hline Ethyl propanoate & 709 & $0.4 \pm 0.1$ & $1.0 \pm 0.1$ & $<0.1$ & $0.9 \pm 0.1$ & nd & MS, RI, ref \\
\hline Isobutyl acetate & 765 & $1 . .0 \pm 0.3$ & $1.3 \pm 0.1^{\mathrm{a}}$ & $0.6 \pm 0.1^{b}$ & $1.2 \pm 0.1$ & nd & MS, RI, ref \\
\hline 2-Methyl-2-butyl acetate & 805 & $2.0 \pm 0.3$ & $1.4 \pm 0.8^{\mathrm{a}}$ & $0.5 \pm 0.1^{b}$ & $1.3 \pm 0.1$ & nd & MS, RI, ref \\
\hline 3-Methyl-1-butyl acetate & 877 & $0.8 \pm 0.2$ & $1.3 \pm 0.1^{b}$ & $0.9 \pm 0.1^{\mathrm{a}}$ & nd & nd & MS, RI, ref \\
\hline Methyl benzoate & 1093 & $0.8 \pm 0.2$ & $1.2 \pm 0.3$ & nd & $1.4 \pm 0.7$ & nd & MS, RI \\
\hline Ethyl octanoate & 1201 & $<0.1$ & $1.2 \pm 0.1$ & nd & nd & nd & MS, RI \\
\hline Ethyl decanoate & 1400 & $0.6 \pm 0.1$ & $0.9 \pm 0.1^{\mathrm{a}}$ & nd & $<0.1$ & nd & MS, RI \\
\hline \multicolumn{8}{|l|}{ Terpenoids } \\
\hline p-Cymene & 1021 & $1.4 \pm 0.1$ & $2.2 \pm 0.3$ & $<0.1$ & $1.0 \pm 0.1^{\mathrm{a}}$ & $0.7 \pm 0.1^{b}$ & MS, RI, ref \\
\hline D-Limonene & 1025 & $0.6 \pm 0.1$ & $2.4 \pm 0.7^{\mathrm{a}}$ & $0.3 \pm 0.1^{b}$ & $1.8 \pm 0.1^{\mathrm{a}}$ & $0.9 \pm 0.1^{b}$ & MS, RI, ref \\
\hline Eucalyptol & 1027 & $0.6 \pm 0.1$ & $1.1 \pm 0.1$ & $<0.1$ & $1.4 \pm 0.3^{\mathrm{a}}$ & $0.9 \pm 0.1^{b}$ & MS, RI, ref \\
\hline Linalool & 1100 & $0.4 \pm 0.1$ & $1.6 \pm 0.2^{\mathrm{a}}$ & $0.4 \pm 0.1^{b}$ & $<0.1$ & $<0.1$ & MS, RI, ref \\
\hline Camphor & 1139 & $0.5 \pm 0.1$ & $1.5 \pm 0.1 \mathrm{ab}$ & $0.8 \pm 0.1 \mathrm{ab}$ & $0.8 \pm 0.1^{\mathrm{a}}$ & $0.3 \pm 0.1^{b}$ & MS, RI, ref \\
\hline Terpinen-4-ol & 1174 & $0.4 \pm 0.1$ & $1.0 \pm 0.1^{\mathrm{a}}$ & $0.7 \pm 0.1^{b}$ & $<0.1$ & $0.6 \pm 0.1$ & MS, RI, ref \\
\hline a-Terpineol & 1189 & $2.3 \pm 0.1$ & $2.0 \pm 0.1^{\mathrm{a}}$ & $1.5 \pm 0.1^{b}$ & $1.1 \pm 0.1$ & $<0.1$ & MS, RI \\
\hline \multicolumn{8}{|l|}{ Others } \\
\hline Furfural & 705 & $12.6 \pm 0.1$ & $0.2 \pm 0.1^{\mathrm{b}}$ & $2.0 \pm 0.1^{\mathrm{a}}$ & $<0.1$ & $0.9 \pm 0.1$ & MS, RI, ref \\
\hline
\end{tabular}

${ }^{1} \mathrm{RI}=$ Experimental retention indices based on the homologous series of $\mathrm{n}$-alkanes (C7-C24); ${ }^{2} \mathrm{MS}=$ Identification confirmed by MS, mass spectra; RI $=$ retention indices provided with NIST14 and FFNSC mass spectral library; ref = identified by comparison to authentic compounds. Unless confirmed by comparison to authentic standards, compounds are considered as tentatively identified.; ${ }^{a-b}$ Different superscript letters in a row at the same time period for non-fermented and fermented pomegranate juice indicates statistically significant differences (ANOVA, Duncan's multiple range test, $p<0.05$ ); nd = not detected. 
The results regarding the preliminary sensory evaluation performed by non-trained testers (consumers) for the evaluation of the produced fermented or non-fermented juices in terms of aroma, taste and overall quality (preference) are presented in Table 4 . No statistically significant differences were observed except from the 4 th week of storage. In that time the consumers preferred more (statistically significant) the fermented pomegranate juice in terms of aroma, taste and overall quality compared to the non-fermented pomegranate juice.

Table 4. Preliminary sensory evaluation of non-fermented and fermented pomegranate juice with Lactobacillus plantarum ATCC 14917 cells during 4 weeks of cold storage.

\begin{tabular}{|c|c|c|c|c|}
\hline Storage Time & Substrate & Aroma & Taste & Overall Quality \\
\hline \multirow[b]{2}{*}{$24 \mathrm{~h}$} & Non-fermented & $8.6 \pm 0.1^{a}$ & $8.5 \pm 0.1^{\mathrm{a}}$ & $8.1 \pm 0.1^{a}$ \\
\hline & Fermented & $8.6 \pm 0.1^{\mathrm{a}}$ & $8.5 \pm 0.1^{\mathrm{a}}$ & $8.2 \pm 0.1^{\mathrm{a}}$ \\
\hline \multirow{2}{*}{ Week 1} & Non-fermented & $7.7 \pm 0.1^{b}$ & $7.6 \pm 0.1^{b}$ & $7.8 \pm 0.1^{b}$ \\
\hline & Fermented & $7.6 \pm 0.1^{b}$ & $7.7 \pm 0.06^{b}$ & $7.8 \pm 0.1^{b}$ \\
\hline \multirow{2}{*}{ Week 2} & Non-fermented & $7.2 \pm 0.1^{\mathrm{c}}$ & $7.1 \pm 0.06^{\mathrm{c}}$ & $7.2 \pm 0.1^{\mathrm{c}}$ \\
\hline & Fermented & $7.3 \pm 0.1^{b}$ & $7.2 \pm 0.1^{\mathrm{c}}$ & $7.2 \pm 0.1^{\mathrm{c}}$ \\
\hline \multirow{2}{*}{ Week 3} & Non-fermented & $6.7 \pm 0.1^{c}$ & $6.4 \pm 0.1^{\mathrm{d}}$ & $6.4 \pm 0.1^{\mathrm{d}}$ \\
\hline & Fermented & $6.9 \pm 0.1^{c}$ & $6.5 \pm 0.1^{\mathrm{d}}$ & $6.4 \pm 0.1^{\mathrm{d}}$ \\
\hline \multirow{2}{*}{ Week 4} & Non-fermented & $5.6 \pm 0.1^{f}$ & $5.3 \pm 0.15^{\mathrm{f}}$ & $5.2 \pm 0.1^{f}$ \\
\hline & Fermented & $6.2 \pm 0.1^{\mathrm{d}}$ & $6.2 \pm 0.1^{\mathrm{d}}$ & $6.2 \pm 0.1^{d}$ \\
\hline
\end{tabular}

Similar superscript letters in columns denotes no significant differences at an alpha $=0.05$ (ANOVA, Duncan Post Hoc Multiple Comparisons).

This interesting finding can be credited to the lactic acid fermentation because it has been stated that lactic acid fermentation can enhance the flavor profile of pomegranate juice and ensure a better control of flavor changes during juice processing [51].

\section{Conclusions}

Application of probiotic Lactobacillus plantarum ATCC 14917 in fermentation of pomegranate juice led to the production of a functional fruit beverage with low alcoholic degree. In particular, fermented pomegranate juice had higher levels of total phenolics content and antioxidant activity compared to non-fermented pomegranate juice during all the period of storage studied. In addition, Lactobacillus plantarum ATCC 14917 retained its viability in high levels (above $8.8 \log \mathrm{cfu} / \mathrm{mL}$ ). Concerning sensorial tests conducted, no significant differences were found between fermented and non-fermented pomegranate juice except from the last week where consumers preferred the fermented juice. Therefore, the tested stain may be used for the production of a novel functional food with high concentration of probiotic bacteria, high nutritional value and acceptance from the consumers.

Author Contributions: Conceptualization, S.P. and I.M.; Methodology, A.B.; Software, A.A.; Validation, I.M., E.B. and S.P.; Formal Analysis, A.T.; Investigation, S.K.; Resources, I.M.; E.B. and S.P.; Data Curation, A.T.; Writing-Original Draft Preparation, I.M.; Writing-Review \& Editing, S.P.; Visualization, I.M.; Supervision, S.P.; Project Administration, S.P.

Funding: This research received no external funding.

Conflicts of Interest: The authors declare no conflict of interest.

\section{References}

1. Brown, L.; Caligiuri, S.P.B.; Brown, D.; Pierce, G.N. Clinical trials using functional foods provide unique challenges. J. Funct. Foods 2018, 45, 233-238. [CrossRef]

2. Terpou, A.; Bosnea, L.; Kanellaki, M.; Plessas, S.; Bekatorou, A.; Bezirtzoglou, E.; Koutinas, A.A. Growth Capacity of a Novel Potential Probiotic Lactobacillus paracasei K5 Strain Incorporated in Industrial White Brined Cheese as an Adjunct Culture. J. Food Sci. 2018, 83, 723-731. [CrossRef] [PubMed] 
3. Santeramo, F.G.; Carlucci, D.; De Devitiis, B.; Seccia, A.; Stasi, A.; Viscecchia, R.; Nardone, G. Emerging trends in European food, diets and food industry. Food Res. Int. 2018, 104, 39-47. [CrossRef] [PubMed]

4. Menrad, K. Market and marketing of functional food in Europe. J. Food Eng. 2003, 56, 181-188. [CrossRef]

5. Bogue, J.; Collins, O.; Troy, A.J. Chapter 2-Market analysis and concept development of functional foods A2-Bagchi, Debasis. In Developing New Functional Food and Nutraceutical Products; Nair, S., Ed.; Academic Press: San Diego, CA, USA, 2017; pp. 29-45.

6. Bhukya, B.; Banoth, S.; Anthappagudem, A. Chapter 5-Saccharomyces cerevisiae as Potential Probiotic: Strategies for Isolation and Selection. In Applied Microbiology and Bioengineering; Shukla, P., Ed.; Academic Press: Cambridge, MA, USA, 2019; pp. 71-85.

7. Ghosh, A.R. Chapter 6-Probiotics in the Rescue of Gut Inflammation. In Therapeutic, Probiotic, and Unconventional Foods; Grumezescu, A.M., Holban, A.M., Eds.; Academic Press: Cambridge, MA, USA, 2018; pp. 101-116.

8. Amara, A.A.; Shibl, A. Role of Probiotics in health improvement, infection control and disease treatment and management. Saudi Pharm. J. 2015, 23, 107-114. [CrossRef] [PubMed]

9. Plessas, S.; Bosnea, L.; Alexopoulos, A.; Bezirtzoglou, E. Potential effects of probiotics in cheese and yogurt production: A review. Eng. Life Sci. 2012, 12, 433-440. [CrossRef]

10. Shori, A.B. The potential applications of probiotics on dairy and non-dairy foods focusing on viability during storage. Biocatal. Agric. Biotechnol. 2015, 4, 423-431. [CrossRef]

11. Terpou, A.; Gialleli, A.I.; Bosnea, L.; Kanellaki, M.; Koutinas, A.A.; Castro, G.R. Novel cheese production by incorporation of sea buckthorn berries (Hippophae rhamnoides L.) supported probiotic cells. LWT Food Sci. Technol. 2017, 79, 616-624. [CrossRef]

12. Koutinas, A.A. 1-Fermented Dairy Products. In Current Developments in Biotechnology and Bioengineering; Elsevier: Amsterdam, The Netherlands, 2017.

13. Perricone, M.; Bevilacqua, A.; Altieri, C.; Sinigaglia, M.; Corbo, R.M. Challenges for the Production of Probiotic Fruit Juices. Beverages 2015, 1. [CrossRef]

14. Da Silva, P.H.F.; Oliveira, V.C.D.; Perin, L.M. Chapter 14-Cow's Milk Protein Allergy and Lactose Intolerance. In Raw Milk; Nero, L.A., De Carvalho, A.F., Eds.; Academic Press: Cambridge, MA, USA, 2019; pp. 295-309.

15. Mantzourani, I.; Nouska, C.; Terpou, A.; Alexopoulos, A.; Bezirtzoglou, E.; Panayiotidis, M.; Galanis, A.; Plessas, S. Production of a Novel Functional Fruit Beverage Consisting of Cornelian Cherry Juice and Probiotic Bacteria. Antioxidants 2018, 7, 163. [CrossRef]

16. Fernandes Pereira, A.L.; Rodrigues, S. Chapter 15-Turning Fruit Juice into Probiotic Beverages. In Fruit Juices; Rajauria, G., Tiwari, B.K., Eds.; Academic Press: San Diego, CA, USA, 2018; pp. $279-287$.

17. Panghal, A.; Janghu, S.; Virkar, K.; Gat, Y.; Kumar, V.; Chhikara, N. Potential non-dairy probiotic products-A healthy approach. Food Biosci. 2018, 21, 80-89. [CrossRef]

18. Dias, C.O.; dos Santos Opuski de Almeida, J.; Pinto, S.S.; de Oliveira Santana, F.C.; Verruck, S.; Müller, C.M.O.; Prudêncio, E.S.; de Mello Castanho Amboni, R.D. Development and physico-chemical characterization of microencapsulated bifidobacteria in passion fruit juice: A functional non-dairy product for probiotic delivery. Food Biosci. 2018, 24, 26-36. [CrossRef]

19. Nakkarach, A.; Withayagiat, U. Comparison of synbiotic beverages produced from riceberry malt extract using selected free and encapsulated probiotic lactic acid bacteria. Agric. Nat. Resour. 2018. [CrossRef]

20. Priyadarshini, A.; Priyadarshini, A. Chapter 2-Market Dimensions of the Fruit Juice Industry. In Fruit Juices; Rajauria, G., Tiwari, B.K., Eds.; Academic Press: San Diego, CA, USA, 2018; pp. 15-32.

21. Shahbaz, H.M.; Kim, J.U.; Kim, S.-H.; Park, J. Chapter 7-Advances in Nonthermal Processing Technologies for Enhanced Microbiological Safety and Quality of Fresh Fruit and Juice Products. In Food Processing for Increased Quality and Consumption; Grumezescu, A.M., Holban, A.M., Eds.; Academic Press: Cambridge, MA, USA, 2018; pp. 179-217.

22. Roberts, D.; Reyes, V.; Bonilla, F.; Dzandu, B.; Liu, C.; Chouljenko, A.; Sathivel, S. Viability of Lactobacillus plantarum NCIMB 8826 in fermented apple juice under simulated gastric and intestinal conditions. LWT 2018, 97, 144-150. [CrossRef]

23. Calabuig-Jiménez, L.; Betoret, E.; Betoret, N.; Patrignani, F.; Barrera, C.; Seguí, L.; Lanciotti, R.; Dalla Rosa, M. High pressures homogenization (HPH) to microencapsulate L. salivarius spp. salivarius in mandarin juice. Probiotic survival and in vitro digestion. J. Food Eng. 2019, 240, 43-48. [CrossRef] 
24. De Godoy Alves Filho, E.; Rodrigues, T.H.S.; Fernandes, F.A.N.; Pereira, A.L.F.; Narain, N.; de Brito, E.S.; Rodrigues, S. Chemometric evaluation of the volatile profile of probiotic melon and probiotic cashew juice. Food Res. Int. 2017, 99, 461-468. [CrossRef] [PubMed]

25. Derakhshan, Z.; Ferrante, M.; Tadi, M.; Ansari, F.; Heydari, A.; Hosseini, M.S.; Conti, G.O.; Sadrabad, E.K. Antioxidant activity and total phenolic content of ethanolic extract of pomegranate peels, juice and seeds. Food Chem. Toxicol. 2018, 114, 108-111. [CrossRef] [PubMed]

26. Plessas, S.; Nouska, C.; Karapetsas, A.; Kazakos, S.; Alexopoulos, A.; Mantzourani, I.; Chondrou, P.; Fournomiti, M.; Galanis, A.; Bezirtzoglou, E. Isolation, characterization and evaluation of the probiotic potential of a novel Lactobacillus strain isolated from Feta-type cheese. Food Chem. 2017, 226, 102-108. [CrossRef]

27. Murthy, S.N.; Patnaik, A.; Srinivasan, N.; Selvarajan, E.; Nivetha, A.; Mohanasrinivasan, V. Fermentative preparation of functional drink from Punica granatum using lactic acid bacteria and exploring its anti-tumor potential. In Proceedings of the IOP Conference Series: Materials Science and Engineering; IOP Publishing: Bristol, UK, 2017.

28. Singh, B.; Singh, J.P.; Kaur, A.; Singh, N. Phenolic compounds as beneficial phytochemicals in pomegranate (Punica granatum L.) peel: A review. Food Chem. 2018, 261, 75-86. [CrossRef]

29. Wang, W.; He, J.; Pan, D.; Wu, Z.; Guo, Y.; Zeng, X.; Lian, L. Metabolomics analysis of Lactobacillus plantarum ATCC 14917 adhesion activity under initial acid and alkali stress. PLoS ONE 2018, 13. [CrossRef]

30. Plessas, S.; Alexopoulos, A.; Bekatorou, A.; Bezirtzoglou, E. Kefir Immobilized on Corn Grains as Biocatalyst for Lactic Acid Fermentation and Sourdough Bread Making. J. Food Sci. 2012, 77, C1256-C1262. [CrossRef] [PubMed]

31. Terpou, A.; Nigam, P.S.; Bosnea, L.; Kanellaki, M. Evaluation of Chios mastic gum as antimicrobial agent and matrix forming material targeting probiotic cell encapsulation for functional fermented milk production. LWT 2018. [CrossRef]

32. Singleton, V.L.; Rossi, J. Colorimetry of Total Phenolics with Phosphomolybdic-Phosphotungstic Acid Reagents. Am. J. Enol. Vitic. 1965, 16, 144-158.

33. Miller, N.J.; Rice-Evans, C.A. Spectrophotometric determination of antioxidant activity. Redox Rep. Commun. Free. Radic. Res. 1996, 2, 161-171. [CrossRef] [PubMed]

34. Gentile, C.; Reig, C.; Corona, O.; Todaro, A.; Mazzaglia, A.; Perrone, A.; Gianguzzi, G.; Agusti, M.; Farina, V. Pomological Traits, Sensory Profile and Nutraceutical Properties of Nine Cultivars of Loquat (Eriobotrya japonica Lindl.) Fruits Grown in Mediterranean Area. Plant Foods Hum. Nutr. 2016, 71, 330-338. [CrossRef] [PubMed]

35. Vázquez-Araújo, L.; Chambers, E.; Adhikari, K.; Carbonell-Barrachina, A.A. Physico-chemical and sensory properties of pomegranate juices with pomegranate albedo and carpellar membranes homogenate. LWT Food Sci. Technol. 2011, 44, 2119-2125. [CrossRef]

36. Plessas, S.; Bekatorou, A.; Gallanagh, J.; Nigam, P.; Koutinas, A.A.; Psarianos, C. Evolution of aroma volatiles during storage of sourdough breads made by mixed cultures of Kluyveromyces marxianus and Lactobacillus delbrueckii ssp. bulgaricus or Lactobacillus helveticus. Food Chem. 2008, 107, 883-889. [CrossRef]

37. Valero-Cases, E.; Nuncio-Jáuregui, N.; Frutos, M.J. Influence of Fermentation with Different Lactic Acid Bacteria and in Vitro Digestion on the Biotransformation of Phenolic Compounds in Fermented Pomegranate Juices. J. Agric. Food Chem. 2017, 65, 6488-6496. [CrossRef]

38. Peres, C.M.; Peres, C.; Hernández-Mendoza, A.; Malcata, F.X. Review on fermented plant materials as carriers and sources of potentially probiotic lactic acid bacteria-With an emphasis on table olives. Trends Food Sci. Technol. 2012, 26, 31-42. [CrossRef]

39. Di Cagno, R.; Coda, R.; De Angelis, M.; Gobbetti, M. Exploitation of vegetables and fruits through lactic acid fermentation. Food Microbiol. 2013, 33, 1-10. [CrossRef]

40. Pimentel, T.C.; Madrona, G.S.; Prudencio, S.H. Probiotic clarified apple juice with oligofructose or sucralose as sugar substitutes: Sensory profile and acceptability. LWT Food Sci. Technol. 2015, 62, 838-846. [CrossRef]

41. Sabokbar, N.; Khodaiyan, F. Total phenolic content and antioxidant activities of pomegranate juice and whey based novel beverage fermented by kefir grains. J. Food Sci. Technol. 2016, 53, 739-747. [CrossRef] [PubMed]

42. Curiel, J.A.; Pinto, D.; Marzani, B.; Filannino, P.; Farris, G.A.; Gobbetti, M.; Rizzello, C.G. Lactic acid fermentation as a tool to enhance the antioxidant properties of Myrtus communis berries. Microb. Cell Factories 2015, 14, 67. [CrossRef] [PubMed] 
43. Coda, R.; Lanera, A.; Trani, A.; Gobbetti, M.; Di Cagno, R. Yogurt-like beverages made of a mixture of cereals, soy and grape must: Microbiology, texture, nutritional and sensory properties. Int. J. Food Microbiol. 2012, 155, 120-127. [CrossRef] [PubMed]

44. Mousavi, Z.E.; Mousavi, S.M.; Razavi, S.H.; Emam-Djomeh, Z.; Kiani, H. Fermentation of pomegranate juice by probiotic lactic acid bacteria. World J. Microbiol. Biotechnol. 2011, 27, 123-128. [CrossRef]

45. Mousavi, Z.E.; Mousavi, S.M.; Razavi, S.H.; Hadinejad, M.; Emam-Djomeh, Z.; Mirzapour, M. Effect of Fermentation of Pomegranate Juice by Lactobacillus plantarum and Lactobacillus acidophilus on the Antioxidant Activity and Metabolism of Sugars, Organic Acids and Phenolic Compounds. Food Biotechnol. 2013, 27, 1-13. [CrossRef]

46. Filannino, P.; Azzi, L.; Cavoski, I.; Vincentini, O.; Rizzello, C.G.; Gobbetti, M.; Di Cagno, R. Exploitation of the health-promoting and sensory properties of organic pomegranate (Punica granatum L.) juice through lactic acid fermentation. Int. J. Food Microbiol. 2013, 163, 184-192. [CrossRef] [PubMed]

47. Lee, I.H.; Hung, Y.-H.; Chou, C.-C. Solid-state fermentation with fungi to enhance the antioxidative activity, total phenolic and anthocyanin contents of black bean. Int. J. Food Microbiol. 2008, 121, 150-156. [CrossRef]

48. Sharma, S.; Kandasamy, S.; Kavitake, D.; Shetty, P.H. Probiotic characterization and antioxidant properties of Weissella confusa KR780676, isolated from an Indian fermented food. LWT 2018, 97, 53-60. [CrossRef]

49. Erdogan, F.S.; Ozarslan, S.; Guzel-Seydim, Z.B.; Kök Taş, T. The effect of kefir produced from natural kefir grains on the intestinal microbial populations and antioxidant capacities of Balb/c mice. Food Res. Int. 2018. [CrossRef]

50. Adewumi, G.A. Health-Promoting Fermented Foods. In Reference Module in Food Science; Elsevier: Amsterdam, The Netherlands, 2018.

51. Di Cagno, R.; Filannino, P.; Gobbetti, M. Lactic acid fermentation drives the optimal volatile flavor-aroma profile of pomegranate juice. Int. J. Food Microbiol. 2017, 248, 56-62. [CrossRef] [PubMed]

52. Allam, H. Impact of Processing on Flavor Volatiles and Physicochemical Properties of Pomegranate Juice. Suez Canal Univ. J. Food Sci. 2016, 3, 67-74. [CrossRef]

53. Beaulieu, J.C.; Obando-Ulloa, J.M. Not-from-concentrate pilot plant 'Wonderful' cultivar pomegranate juice changes: Volatiles. Food Chem. 2017, 229, 553-564. [CrossRef] [PubMed]

54. Jung, J.S. Analysis of volatile compounds in the root peel, stem peel, and fruit peel of pomegranate (Punica granatum) by TD GC/MS. Int. J. Bio-Sci. Bio-Technol. 2014, 6, 169-181. [CrossRef]

55. Andreu-Sevilla, A.J.; Mena, P.; Martí, N.; García Viguera, C.; Carbonell-Barrachina, Á.A. Volatile composition and descriptive sensory analysis of pomegranate juice and wine. Food Res. Int. 2013, 54, 246-254. [CrossRef]

56. Calín-Sánchez, Á.; Martínez, J.J.; Vázquez-Araújo, L.; Burló, F.; Melgarejo, P.; Carbonell-Barrachina, Á.A. Volatile composition and sensory quality of Spanish pomegranates (Punica granatum L.). J. Sci. Food Agric. 2011, 91, 586-592. [CrossRef] [PubMed]

57. De Sousa Galvão, M.; Narain, N.; do Socorro Porto dos Santos, M.; Nunes, M.L. Volatile compounds and descriptive odor attributes in umbu (Spondias tuberosa) fruits during maturation. Food Res. Int. 2011, 44, 1919-1926. [CrossRef]

58. Servili, M.; Selvaggini, R.; Taticchi, A.; Begliomini, A.L.; Montedoro, G. Relationships between the volatile compounds evaluated by solid phase microextraction and the thermal treatment of tomato juice: Optimization of the blanching parameters. Food Chem. 2000, 71, 407-415. [CrossRef]

59. Luna, G.; Morales, M.T.; Aparicio, R. Characterisation of 39 varietal virgin olive oils by their volatile compositions. Food Chem. 2006, 98, 243-252. [CrossRef]

60. Tripathi, J.; Chatterjee, S.; Gamre, S.; Chattopadhyay, S.; Variyar, P.S.; Sharma, A. Analysis of free and bound aroma compounds of pomegranate (Punica granatum L.). LWT Food Sci. Technol. 2014, 59, 461-466. [CrossRef]

(C) 2018 by the authors. Licensee MDPI, Basel, Switzerland. This article is an open access article distributed under the terms and conditions of the Creative Commons Attribution (CC BY) license (http:/ / creativecommons.org/licenses/by/4.0/). 